\title{
Implementasi Strategi Multiple Intelligences pada Pembelajaran Bahasa Inggris (Studi Kasus di SD Inklusi Semai Jepara)
}

\author{
Santi Andriyani \\ Fakultas Tarbiyah dan Ilmu Keguruan UNISNU Jepara \\ e-mail: santiandriyani6@gmail.com.
}

\begin{abstract}
This study is aimed at: (1) describing the importance of multiple intelligences strategy in English learning and (2) describing the implementation of multiple intelligences strategy in English learning at SD Inklusi Semai Jepara. The writer uses Case Study method to describe deeply the implementation of multiple intelligences strategy in English learning at SD Inklusi Semai Jepara. Besides, the writer tries to find out the phenomenon in implementing of multiple intelligences strategy in English learning at SD Inklusi Semai Jepara.The findings of this study are: (1) The implementation of the MI method in SD Inklusi Semai Jepara has been starting since 2011; (2) the strategies that usually used in English learning are identification, clasification, song, games, simulation, and role play; (3)The contents of the lesson plan made by English teachers are identity, eksploration, elaboration, confirmation, MI strategy, and authentic assesment; (4) the supporting factors in implementing of multiple intelligences strategy in English learning at SD Inklusi Semai Jepara are from teachers, students, and parents; (5)the inhibiting factor in implementing of MI strategy in English learning at SD Inklusi Semai Jepara is the limited time for teachers in preparing all of the class administrations.
\end{abstract}

Keywords: Multiple intelligences strategies, English for young learner, Case study. 


\section{Pendahuluan}

Di era globalisasi sekarang, bahasa Inggris merupakan bahasa yang penting yang harus dikuasai oleh setiap orang mulai dari anak-anak hingga dewasa. Oleh karena itu, sejak usia dini yaitu TK dan SD, anak-anak sudah di kenalkan dengan bahasa Inggris. Meskipun dalam kurikulum 2013 bahasa Inggris di sekolah dasar tidak menjadi mata pelajaran wajib, namun sebagian besar sekolah masih mengajarkan bahasa Inggris sebagai muatan lokal. Hal itu dimaksudkan supaya setiap orang tidak akan gagap terhadap teknologi, komunikasi dan informasi yang melaju pesat ke seluruh penjuru dunia.

Pentingnya bahasa Inggris untuk anak -anak juga dikemukakan oleh Trawick Smith (dalam Andriani, 2011) menyatakan bahwa:

Ketika seorang belajar untuk berbicara dua atau lebih bahasa dirinya akan cenderung untuk memilih salah satu diantara bahasa tersebut untuk menggambarkan sebuah objek atau konsep. Jika dua bahasa digunakan didalam rumah, maka anak usia 18 tahun keatas akan cenderung menggunakan kedua bahasa tersebut dan memilih serta dapat mengenal bahasa yang dipergunakan masing-masing anggota keluarganya.

Keberhasilan pembelajaran bahasa Inggris untuk anak SD sangat dipengaruhi oleh metode pembelajaran. Metode dan strategi pembelajaran merupakan cara dan tehnik yang dilakukan oleh guru dalam menyampaikan materi. Penggunaan metode dan strategi pembelajaran yang inovatif dan kreatif akan memberikan dampak yang positif terhadap keberhasilan siswa, sebaliknya penggunaan metode dan strategi pmbelajaran yang hanya bersifat konvensional akan memberikan kejenuhan, kebosanan dalam PBM dan pada akhirnya tujuan pembelajaran tidak dapat tercapai dengan maksimal.

Namun pada kenyataannya, masih banyak sekolah yang tidak menggunakan metode pembelajaran secara inovatif dan kreatif. Dalam proses pembelajaran 
disekolah, guru masih banyak yang menggunakan prinsip teacher-centered dan mengesampingkan pembelajaran yang bersifat student-centered termasuk pembelajaran Bahasa Inggris. Seperti hasil wawancara penulis dengan salah satu guru bahasa Inggris di SD kawasan Jepara pada tanggal 12 Mei 2016. Guru tersebut mengatakan bahwa metode yang digunakan dalam mengajar bahasa Inggris masih menggunakan metode konvensional yaitu ceramah dan drill. Dia juga menambahkan bahwa hasil belajar bahasa Inggris para siswanya kurang maksimal dan hanya bersifat formalitas saja.

Berdasarkan data yang peneliti ambil dari https://goresangurusemai. wordpress.com/2013/08/23/semai-rintisan-sekolahnya-manusia-di-bumi-jepara/. pada tanggal 19 Mei 2016. SD Semai merupakan sekolah dasar yang memiliki nilainilai humanis yang mengedepankan semua potensi anak dan tidak membeda-bedakan fisik anak didik. Dalam proses belajar mengajarnya, para guru juga selalu mengedepankan penggalian semua potensi anak. Dalam hal ini, model pembelajaran di SD Semai adalah berdasarkan pada kecenderungan kecerdasan yang dimiliki oleh siswa.

Oleh karena itu, penulis akan melakukan penelitian yang mendalam dan komprehensif mengenai implementasi strategi multiple intelligences dalam pembelajaran bahasa Inggris di SD Semai Jepara. Penulis ingin menggali lebih mendalam mengenai keunikan dan kekhasan strategi yang di gunakan di SD Semai. Selain itu, penulis ingin meneliti lebih detail mengenai keterkaitan antara strategi tersebut dengan peningkatan kemampuan bahasa Inggris siswa.

Alasan pemilihan lokasi penelitian di lakukan di SD Semai Jepara adalah : (1) SD Semai Jepara adalah satu-satunya sekolah yang ada di Jepara yang menggunakan strategi multiple intelligences dalam proses belajar mengajar; (2) Berdasarkan hasil observasi dan wawancara awal kepada beberapa guru SD Semai Jepara, penggunaan strategi multiple intelligences memberikan keleluasaan pada guru untuk melakukan 
pembelajaran sesuai dengan gaya belajar anak; dan (3) Dengan menggunakan strategi multiple intelligences, maka guru menjadi katalisator dan fasilitator proses transfer knowledge yang asyik. Guru mampu membuat Lesson plan yang sesuai dengan learning style murid-muridnya.

Rumusan masalah pada penelitian yaitu: (1) Mengapa konsep strategi multiple intelligences diperlukan dalam pembelajaran bahasa Inggris di SD Inklusi Semai Jepara?; (2) Bagaimanakah implementasi strategi multiple intelligences dalam pembelajaran bahasa Inggris di SD Inklusi Semai Jepara?

Tujuan dari penelitian ini adalah untuk mengetahui dan mendiskripsikan tentang: (1) Pentingnya strategi multiple intelligences dalam pembelajaran bahasa Inggris di SD inklusi Semai Jepara dan (2) Implementasi strategi multiple intelligences dalam pembelajaran bahasa Inggris di SD Inklusi Semai Jepara

\section{Konsep Multiple Intelligences (MI)}

Seorang ahli pendidikan dari Hardvard University bernama Howard Gardner berpendapat bahwa tidak ada manusia yang tidak cerdas. Paradigma ini menentang teori dikotomi cerdas-tidak cerdas. Gardner juga menentang anggapan cerdas dari sisi IQ, yang menurutnya hanya mengacu pada tiga kecerdasan, yakni logikomatematik, linguistik, dan spasial (Tadzkiroatun Musfiroh:2008).

Pada tahun 1983 Howard Gardner menampilkan teori kecerdasan yang baru bernama Multiple Intelligences. Gardner telah menguak rumpun kecerdasan yang lebih luas dari pada kepercayaan manusia sebelumnya, serta menghasilkan definisi kecerdasan sesuai paradigma multiple intellingences. Gardner mendefinisikan kecerdasan kedalam 3 komponen yaitu: (1) kemampuan untuk menyelesaikan masalah yang terjadi dalam kehidupan nyata sehari - hari; (2) kemampuan untuk menghasilkan persoalan - persoalan baru yang dihadapi untuk diselesaikan; dan (3) 
kemampuan untuk menciptakan sesuatu atau menawarkan jasa yang akan menimbulkan penghargaan dalam budaya seseorang (Linda Campbell: 2002).

Temuan kecerdasan menurut Multiple Intelligences, telah mengalami perkembangan sejak pertama kali ditemukan. Pada awalnya, Howard Gardner menemukan tujuh kecerdasan, setelah itu berkembang menjadi 8 kecerdasan, yakni naturalis, terakhir Gardner memunculkan adanya kecerdasan yang ke-9 yaitu kecerdasan eksistensial (Tadzkiroatun: 2008). Oleh karena itu disimpulkan bahwa kecerdasan dalam Multiple Intelligences meliputi kecerdasan verbal-linguistik, kecerdasan logis-matematis, kecerdasan visual-spasial, kecerdasan musikal, kecerdasan kinestetis, kecerdasan interpersonal, kecerdasan intrapersonal, kecerdasan naturalis dan kecerdasan eksistensial.

Lebih lanjut, menurut Tadzkiroatun Musfiroh (2008:1.4) Gardner menjelaskan karakteristik Multiple Intelligences sebagai berikut:

1. Semua intelligensi itu berbeda - beda, tetapi semuanya sederajat.

2. Semua kecerdasan dimiliki manusia dalam kadar yang tidak persis sama. Semua kecerdasan dapat di eksplorasi, ditumbuhkan, dan dikembangkan secara optimal.

3. Terdapat banyak indikator kecerdasan dalam tiap - tiap kecerdasan.

4. Semua kecerdasan yang berbeda - beda tersebut akan saling bekerjasama untuk mewujudkan aktivitas yang diperbuat manusia. Satu kegiatan mungkin memerlukan lebih dari satu kecerdasan, dan satu kecerdasan dapat dipergunakan dalam berbagai bidang.

5. Semua jenis kecerdasan tersebut ditemukan diseluruh atau semua lintas kebudayaan diseluruh dunia dan kelompok usia.

6. Tahap - tahap alami dari setiap kecerdasan dimulai dengan kemampuan membuat pola dasar.

7. Saat seorang dewasa, kecerdasan diekspresikan melalui rentang pengejaran profesi dan hobi.

Dari paparan karakteristik Multiple Intelligences diatas menunjukkan bahwa setiap anak mempunyai banyak kecerdasan meskipun kadarnya berbeda-beda (baik, cukup dan kurang), namun kecerdasan tersebut dapat dikembangkan dalam kegiatan 
sehari - hari dan tiap anak mempunyai cara sendiri - sendiri dalam menunjukkan kecerdasannya.

\section{Strategi Pembelajaram Multiple Intelligences ( MI )}

Strategi pembelajaran berbasis multiple intelligences yang ditemukan dan dilakukan secara langsung oleh Munif Chatif di sekolah - sekolah binaannya (Munif Chatib, 2011: 131-133) adalah: pertama, Strategi Diskusi. yaitu aktifitas pembelajaran dengan komunikasi dan interaksi diantara dua orang atau lebih. Pada diskusi, harus terdapat topik berupa masalah yang akan dipecahkan; kedua, Strategi Action Research. Strategi ini merupakan aktifitas pembelajaran yang meminta siswa untuk membuat hipotesis terhadap materi terlebih dahulu. Hipotesis tersebut kemudian dibuktikan dengan pengumpulan data, melakukan analisis, dan berakhir dengan kesimpulan.

Ketiga, Strategi Klasifikasi. Yaitu aktifitas belajar dengan cara melakukan pengelompokan banyak data ke dalam-minimal-dua area atau premis yang berbeda berdasarkan kriteria, ciri-ciri dan indikator tertentu. Keempat, Strategi Analogi. Ini merupakan pemahaman konsep dengan cara membuat persamaan suatu bentuk dengan bentuk lainnya, yang mengakibatkan adanya hubungan kesamaan dia antaranya sehingga dapat memecahkan masalah yang dihadapi berikutnya. Kelima, Strategi Identifikasi. Hal ini adalah pemahaman konsep dengan cara mencari beberapa ciri yang melekat pada sebuah objek. Adapun prosedurnya adalah: objek atau konsep, proses identifikasi dan hasil identifikasi.

Ketujuh adalah Strategi Sosiodrama. Maksudnya adalah strategi yang mempunyai poin-poin penting sebagai berikut: pemeran, skenario/naskah, daftar skenario, teaching aids dan pertanyaan umpan balik. Adapun pendekatan multiple intelligences adalah dalam ranah linguistik, kinestetik dan interpersonal. Kedelapan yaitu Strategi Penokohan. Ini merupakan strategi pembelajaran yang mengkaitkan 
konsep pembelajaran dengan sosok terkenal. Penokohan membantu siswa menghafal dan memahami konsep tertentu. Kesembilan yaitu Strategi Flash-Card. Konsep ini merupakan strategi pembelajaran yang mengaitkan konsep pembelajaran dengan gambar dalam kartu. Pola permainan kartu ini bisa beragam, antara lain pola kwartet, urutan atau yang lain.

Kesepuluh adalah Strategi Gambar Visual. Yakni strategi pembelajaran yang mengaitkan konsep pembelajaran dengan gambar, lambang, atau simbol tertentu. Kesebelas adalah Strategi wayang. Ini merupakan strategi pembelajaran yang mengaitkan konsep pembelajaran dengan dialog tokoh- tokoh yang ada hubungannya dengan konsep atau materi. Keduabelas adalah Strategi Applied Learning. Merupakan strategi pembelajaran yang mengaitkan konsep pembelajaran dengan manfaatnya untuk kebutuhan sehari - hari. Materi tidak dibiarkan menjadi abstrak, tapi dapat langsung dipraktekkan dalam kehidupan sehari - hari.

Ketiga belas adalah Movie Learning. Ini merupakan strategi pembelajaran yang mengaitkan konsep pembelajaran dengan tayangan film. Tentunya target pembelajaran terangkum dalam film tersebut. Keempat belas adalah Strategi Environment Learning. Maksudnya adalah strategi pembelajaran dengan mengunjungi suatu tempat yang punya managemen tertentu. Konsepnya adalah get something, artinya siswa akan mendapatkan pengetahuan dan informasi dari lingkungan yang dikunjungi. Kelima belas yakni Strategi Service Learning. Ini merupakan strategi pembelajaran dengan mengunjungi suatu tempat (fasilitas publik) atau lingkungan tertentu dengan melakukan pelayanan informasi kepada tempat tersebut. Siswa melakukan pelayanan atau servise kepada lingkungan berdasarkan materi yang sudah dikuasai di kelas.

Di Indonesia, penelitian mengenai strategi multiple intelligences memang cukup banyak dilakukan. Rata-rata penelitian tersebut menghasilkan temuan yang positif. Diantaranya adalah: 
Penelitian tentang $M I$ yang dilakukan oleh Siti Kamilah dengan judul Implementasi Pendekatan Multiple Intelligences dalam Pembelajaran Anak Usia Dini di Playgroup dan Kindergarden ANANDA MENTARI Condongcatur Yogyakarta tahun 2015. Hasil penelitian menunjukkan bahwa pembelajaran bagi peserta didik dengan menggunakan pendekatan multiple intelligences memberikan dampak positif bagi siswa, meningkatkan rasa percaya diri, dan melibatkan seluruh potensi siswa.

Selanjutnya, penelitian yang dilaksanakan oleh Muflihatun Thohiroh dengan judul Implementasi Multiple Intelligences dalam Pembelajaran pada SD Berbasis Islam di kota Magelang; Studi Kasus di SD Muhammadiyah 1 Alternatif dan SDIT Ihsanul Fikri Kota Magelang tahun 2013 . Hasil penelitian menunjukkan bahwa kerangka konseptual implementasi multiple intelligences memiliki 3 tahap yaitu: tahap input, tahap proses, dan tahap output. Selain itu, hasil penelitian ini juga menunjukkan dampak positif dalam penggunaan metode multiple intelligences yaitu meningkatkan prestasi siswa, sering menjuarai lomba baik tingkat lokal maupun nasional, serta berdampak pada kepribadian siswa secara positif.

\section{Metode Penelitian}

Penelitian ini menggunakan metode penelitian studi kasus karena peneliti akan melakukan eksplorasi secara mendalam terhadap program, kejadian, proses, aktifitas mengenai implementasi strategi multiple intelligencesdalam pembelajaran bahasa Inggris, terhadap suatu komunitasyang bergerak dalam bidang pendidikan yaitu SD Semai Jepara Jawa Tengah.

Hal ini sesuai dengan yang dikemukakan oleh Creswell (2007:73), studi kasus adalah merupakan salah satu jenis penelitian kualitatif, dimana peneliti melakukan eksplorasi secara mendalam terhadap program, kejadian, proses, aktifitas, terhadap satu atau lebih orang. 
Lokasi penelitian ini adalah di SD Semai Desa Senenan Kecamatan Tahunan Kabupaten Jepara Provinsi Jawa Tengah. Sekolah tersebut dipilih karena hanya SD Semai yang di Senenan yang melakukan pembelajaran berbasis pada multiple intelligences. Adapun waktu pelaksanaan penelitian ini yaitu selama 5 bulan.

Objek dalam penelitian ini adalah SD Semai Jepara yang difokuskan pada kegiatan rutinitas dan proses kegiatan belajar mengajar bahasa Inggris di SD Semai Jepara, sehingga mengetahui implementasi strategi multiple intelligences dalam pembelajaran bahasa Inggris secara menyeluruh. Sebagai subjek (responden) dalam penelitian ini adalah orang yang mempunyai kapasitas sebagai sumber informasi penelitian yang dipilih secara purposif, adapun responden dari penelitian ini yaitu: Pengurus Yayasan SD Semai yaitu Ibu Mujtahidah, S.Pd.I; Kepala Sekolah SD Semai yaitu Ibu Tri S.Pd.I; Guru Bahasa Inggris SD Semai yaitu Ibu Ririn S.Pd.I, Koordinator English Club yaitu Ibu Nurul Muallifah, S.Pd.I, wali murid SD Semai yaitu bunda Ive, dan dua siswa SD Semai yaitu Ananda Alfa.

Tahapan pengumpulan data dibagi dalam tiga tahap yaitu: (1) tahap Pra Lapangan sebelum memasuki lapangan penelitian; (2) tahap pekerjaan lapangan; dan (3) tahap analisis data (Moleang, 2006:127).

1. Teknik Pengumpulan data

Teknik pengumpulan data dalam penelitian ini menggunakan : (1) observasi (pengamatan); (2) interview (wawancara); (3) dokumentasi; (4) gabungan (Sugiyono, 2012:63) serta dengan (5) Materi audio dan visual (Creswell, 2010: 270). Dalam penelitian kualitatif, observasi partisipatif, interview kualitatif, rekam audio, rekam video, dan pengambilan potografi dilakukan secara alami (nature) sebagai bagian dari realitas sosial SD Semai Jepara Jawa Tengah.

2. Keabsahan Data

Pada penelitian ini yang akan digunakan hanyalah kriteria derajat kepercayaan (kredibilitas) sebagai pengukur keabsahan data dan dalam pengujian derajat 
kepercayaan penelitian ini menggunakan triangulasi seperti yang dikemukakan oleh Noeng Muhajir (2002:172).

\section{Analisis Induktif}

Teknik analisis data yang digunakan dalam penelitian ini adalah analisis data kualitatif. Dalam penelitian kualitatif aspek proses lebih ditekankan daripada hanya sekedar hasil, dan penelitian kualitatif mempunyai medan yang alami sebagai sumber data langsung sehingga bersifat deskriptif naturalistik

Data-data yang terbangkitkan, baik melalui interview, observasi partisipatif, analisis dokumen, analisis simbol-simbol, kemudian di reduksi (merangkum memilih hal-hal yang pokok, memfokuskan pada hal-hal yang penting sesuai dengan tema) dan membuang data-data yang tidak penting. Masing-masing baris data diberi kode dengan masing-masing pertanyaan penelitian.

\section{Hasil penelitian}

\section{Sejarah strategi multiple intelligences di SD Inklusi Semai Jepara}

Strategi MI mulai dikenal oleh SD Semai Jepara sejak tahun 2010. Awal mulanya adalah ketertarikan para pengurus yayasan Semai dan guru-guru Semai dengan terbitnya buku Sekolahnya Manusia karya bapak Munif Chatib. Buku Sekolahnya Manusia menggambarkan tentang bagaimana konsep sekolah yang humanis. Konsep sekolah yang menganggap semua anak adalah bintang dan memiliki kelebihan dan kecerdasan masing-masing. Dari situlah kemudian, salah satu pengurus yayasan yaitu Ibu Laila Jauharoh kemudian berniat mendalami konsep MI tersebut dengan mengikuti perkuliahan pak Munif yaitu bernama GA (Guardian Angel) angkatan ke lima di Surabaya. 


\section{Urgensi Aplikasi MI dalam pembelajaran bahasa Inggris}

Berdasarkan wawancara dengan Kepala Sekolah SD Semai pada tanggal 04 Oktober 2016 di SD Semai Jepara, beliau menyatakan bahwa alasan mengimplementasikan strategi MI di SD Semai karena kita menganggap semua anak adalah bintang. Sehingga dengan menggunakan strategi MI dalam pembelajaran, maka semua potensi anak akan bisa digali dan dikembangkan dengan maksimal.

Pentingnya strategi MI ini dalam pembelajaran bahasa Inggris adalah banyaknya metode yang bisa digunakan oleh guru bahasa Inggris dalam proses belajar mengajar. Sehingga, kemampuan bahasa Inggris siswa seperti penguasaan vocabularies, reading, dan speaking dapat berkembang secara maksimal. Hal ini dapat terjadi karena metode yang digunakan dalam MI disesuaikan dengan kebutuhan materi dan cara belajar siswa.

Hasil observasi di kelas yang telah dilakukan oleh peneliti menunjukkan bahwa penggunaan strategi MI dalam pembelajaran bahasa Inggris dapat meningkatkan minat dan antusiasme belajar siswa. Selain itu, kemampuan bahasa Inggris siswa juga berkembang. Suasana pembelajaran dikelas menjadi aktif, menarik, dan menyenangkan. Salah satu contohnya, penggunaan metode parodi dalam peningkatan kosakata bahasa Inggris siswa.

Oleh karena itu ada beberapa argumentasi mengapa MI penting dalam pembelajaran, yaitu:

a. Strategi MI berupaya untuk melejitkan setiap siswa sesuai kecerdasan uniknya;

b. Strategi MI memiliki karakteristik yaitu menjadikan pembelajaran menjadi menyenangkan dan menarik; dan

c. Dengan menggunakan strategi MI maka paradigma guru dan wali murid memiliki satu frame yaitu menganggap bahwa semua anak adalah istimewa. 


\section{Manfaat Menggunakan Strategi MI}

Berdasarkan hasil wawancara dengan wali murid SD Semai yaitu pada tanggal 29 September 2016 pada pukul 13.00 - 14.00 WIB di Rumah kediaman Wakil Ketua Komite Sekolah Semai, beliau menyampaikan bahwa dengan menggunakan strategi MI dalam pembelajaran anak, maka anak akan merasa enjoy, tidak tertekan, dan memiliki kemandirian.

Dengan menggunakan strategi MI dalam pembelajaran bahasa Inggris, maka kekhawatiran siswa tentang bahasa Inggris yang menjadi momok telah hilang. Para siswa mendapatkan banyak manfaat dari implementasi strategi tersebut. Dari sisi kognitif, pengetahuan bahasa Inggris siswa meningkat secara maksimal. Dari sisi psikologis, para siswa merasa enjoy, nyaman, tidak boring dalam mengikuti pembelajaran bahasa Inggris. Kemudian dari sisi perkembangan sosial-emosional, kemampuan siswa dalam bekerjasama dan kolaborasi dengan teman semakin terasah karena berbagai metode yang digunakan dalam pembelajaran. Dalam pengembangan psikomotorik siswa, strategi ini memiliki manfaat yang signifikan karena strategi MI ini bersifat active learning. Selain itu, dari sisi perkembangan bahasa anak, berbagai metode yang bersifat praktik dapat meningkatkan keterampilan berkomunikasi anak dan juga meningkatkan linguistik anak.

Manfaat strategi MI tidak hanya dirasakan oleh siswa, melainkan juga guru dan wali murid. Dengan menggunakan strategi MI dalam proses pembelajaran, maka guru SD Semai dituntut untuk selalu berinovasi dan memiliki kreatifitas yang tinggi dalam proses belajar mengajar dengan para siswanya. Selain itu, para guru harus menguasai berbagai metode pembelajaran, konsep kecerdasan majemuk, dan karakteristik siswa.

Para wali murid juga merasakan manfaat yang besar dengan adanya strategi MI tersebut. Manfaat yang didapat ada dua aspek, yang pertama dari aspek anaknya yaitu memiliki kemandirian dan kratifitas yang tinggi. Yang kedua dari aspek 
internal wali murid, yaitu para wali murid terlibat aktif dalam kegiatan-kegiatan para anaknya terutama pada puncak tema perminggu. Strategi MI ini memang melibatkan seluruh komponen termasuk orang tua sebagai partner pendukung siswa dalam mencapai keberhasilan pendidikan.

\section{Jenis strategi MI dalam pembelajaran bahasa Inggris}

Sesuai dengan hasil temuan yaitu hasil wawancara dengan guru bahasa Inggris pada tanggal 09 Oktober 2016 dan pada tanggal 10 Oktober 2016, maka di SD Inklusi Semai Jepara, metode pembelajaran MI yang sering digunakan dalam pembelajaran bahasa Inggris adalah: Strategi klasifikasi, identifikasi, sosiodrama, flash card, gambar visual, applied learning, games dan parodi.

Implementasi strategi klasifikasi di SD Semai dalam pembelajaran bahasa Inggris adalah guru telah menyiapkan worksheet mengenai kosakata bahasa Inggris dengan berbagai tema yang disusun secara acak, kemdian guru memberikan petunjuk kepada siswa untuk mengklasifikasikan kosakata tersebut sesuai dengan tema. Para siswa diharapkan mampu mengklasifikasikan osajata bahasa Inggris secara tepat dan sesuai.

Hampir sama dengan klasifikasi, strategi identifikasi yang dilaksanakan dalam pembelajaran bahasa Inggris adalah mengidentifikasi kosakata bahasa Inggris yang masuk dalam tema-tema yang ditentukan oleh guru sesuai dengan lesson plan yang disusun. Contohnya adalah things in the living room, things in the bathroom,things in the kithcen, dan lain sebagainya.

Adapun implementasi metode sosiodrama dalam pembelajaran bahasa Inggris di SD Semai dimaksudkan untuk memberikan pengetahuan dan informasi dengan melalui praktik secara langsung. Guru bahasa Inggris menyiapkan skenario mengenai materi yang akan dipelajari. Setelah guru memberikan materi, kemudian para siswa 
diminta untuk melakukan praktik sesuai dengan materi tersebut. Hal ini bertujuan untuk meningkatkan kemampuan speaking, sosial, dan juga kepercayaan diri siswa.

Dalam pembelajaran bahasa Inggris, sebagian besar guru bahasa Inggris selalu menggunakan metode gambar visual dalam proses belajar mengajar. Gambar visual ini memberikan konsep nyata, bukan abstrak kepada para siswa sehingga para siswa dapat memahami materi tersebut secara komprehensif. Biasanya, kosakata kosakata bahasa Inggris yang dipelajari di SD Semai kemudian disertai dengan gambar visual tidak hanya berupa tulisan saja. Gambar visual tersebut biasanya dalam bentuk video visual, ppt, atau bentuk cetak.

Metode games dalam pembelajaran bahasa Inggris, biasanya dilakukan oleh guru diawal dan akhir pembelajaran. Ini bertujuan untuk mengecek pemahaman para siswa terhadap materi yang sebelumnya dan materi yang telah diajarkan pada saat itu. Bentuk games yang dilaksanakan biasanya bersifat individu dan group. Supaya pembelajaran bahasa Inggris tidak hanya sebatas menjadi pengetahuan saja, tetapi dapat bermanfaat dalam kehidupan sehari-hari, maka para guru bahasa Inggris menggunakan strategi applied learning. Salah satu contoh implementasinya adalah materi tentang "In the Market". Guru menyiapkan berbagai hal yang terkait dengan materi kemudian guru juga memberikan penjelasan mengenai cara membeli barang di pasar. Strategi pembelajaran ini mengaitkan konsep pembelajaran dengan manfaatnya untuk kebutuhan sehari - hari. Materi tidak dibiarkan menjadi abstrak, tapi dapat langsung dipraktekkan dalam kehidupan sehari - hari.

Berikut beberapa gambar yang menunjukkan aktifitas anak menggunakan strategi MI.

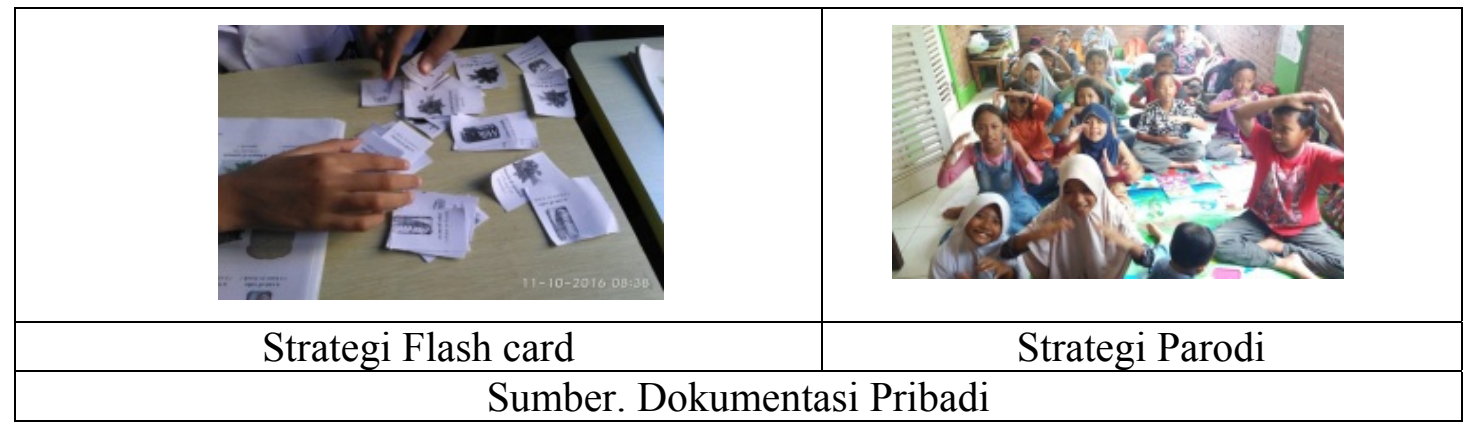


Metode yang selalu membuat para siswa senang dan enjoy adalah metode parodi. Implementasi metode parodi ini adalah guru menyiapkan lagu sesuai dengan materi yang diajarkan. Lagu tersebut bisa ciptaan sendiri atau adopsi dari lagu-lagu yang sudah dikenal para siswa. Dengan metode ini, para siswa secara mudah dan cepat mengingat materi bahasa Inggris yang telah diajarkan.

Untuk Implementasi PBM bahasa Inggris dengan menggunakan strategi MI

\begin{tabular}{|l|l|}
\hline Ini adalah scene setting dengan \\
tema quantity dan buku paket \\
bahasa Inggris kelas 6
\end{tabular}

di SD Semai, para guru memasukkan SK KD yang sesuai dengan aturan dinas Pendidikan kabupaten Jepara kemudian guru-guru bahasa Inggris mengembangkannya dengan bentuk Lesson Plan yang acuannya adalah panduan lesson plan dari bukunya pak Munif Chatib yang berjudul Gurunya Manusia.

Berikut ini adalah beberapa gambar hasil observasi peneliti dalam PBM bahasa Inggris di kelas 6:

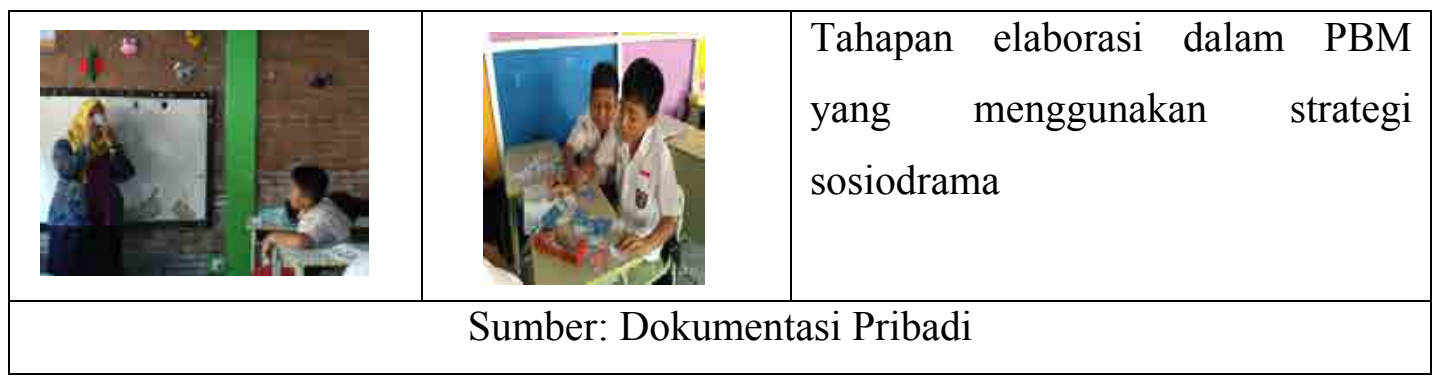

\section{Faktor Pendukung Internal}

Berdasarkan hasil wawancara dengan beberapa responden, ada beberapa faktor pendukung internal dalam pelaksanaan strategi MI dalam pembelajaran bahasa Inggris di SD Inklusi Semai Jepara. 
Pertama, dari pihak guru SD Semai. Guru-guru SD Semai termasuk guru bahasa Inggris beserta tenaga kependidikannya memiliki semangat yang tinggi dalam melaksanakan konsep tersebut. Para guru juga selalu difasilitasi untuk capasity building dan dikirim untuk mengikuti pelatihan-pelatihan dalam rangka meningkatkan profesionalitas guru-guru tersebut.

Kedua, dari pihak siswa SD Semai sendiri. Siswa-siswa SD Semai merupakan faktor pendukung internal dalam pelaksanaan strategi MI dalam pembelajaran bahasa Inggris. Para siswa memiliki semangat untuk belajar dan memiliki tingkat curiosity yang tinggi sehingga sangat cocok dan nyaman dengan menggunakan strategi MI.

\section{Faktor pendukung eksternal}

Berdasarkan hasil wawancara dengan beberapa responden, maka faktor pendukung dari eksternal sebagai berikut:

Pertama, wali murid SD Semai yang memiliki kepedulian terhadap segala aktifitas SD Semai yang berkaitan dengan perkembangan siswa. Wali murid mendukung penuh segala aktifitas yang berkaitan dengan kembang tumbuh anakanaknya. Biasanya dukungan tersebut terlihat saat puncak tema kegiatan sekolah berupa kegiatan bersih pantai, kunjungan ke rumah teman dan lain sebagainya

Kedua, dari pihak luar seperti dinas pendidikan kecamatan dan KKG di wilayah kecamatan Tahunan. Disdikpora Tahunan mendukung semua program sekolah Semai. KKG juga merespon positif keberadaan guru-guru Semai terbukti dengan ditunjuknya beberapa guru semai untuk menjadi narasumber dari kegiatankegiatan KKG.

\section{Faktor Penghambat Internal}

Faktor penghambat dalam implementasi strategi MI pada pembelajaran bahasa Inggris adalah terkait terbatasnya waktu bagi para guru dalam mempersiapkan segala administrasi kelas. Hal ini dikarenakan hari aktif di Semai hanya 4 hari dan 1 harinya adalah khusus untuk ekstrakulikuler semua bakat. Maka dari itu, terkadang guru bahasa Inggris tidak tepat waktu dalam menyelesaikan administrasi kelas. 
Faktor kedua adalah dari siswa. Hasil dari wawancara peneliti dengan salah satu responden, bahwa ada beberapa siswa yang belum welcome dengan temantemannya yang memiliki kondisi $\mathrm{ABK}$ sehingga terkadan dalam proses pembelajaran bahasa Inggris butuh penanganan lebih ekstra

\section{Kegiatan Penunjang Pembelajaran Bahasa Inggris}

Pembelajaran bahasa Inggris akan semakin mudah dan tercapai sesuai dengan tujuan, maka perlu adanya kegiatan yang mendukung hal tersebut. Hal tersebut dilakukan oleh SD Semai dengan mengadakan English Club untuk anak-anak yang minat pada skil bahasa Inggris.

Adapun referensi yang dipakai dalam kegiatan English Club adalah English Time yang memang sejak berdirinya Semai pembelajaran bahasa Inggris menggunakan media tersebut. English Time merupakan sebuah paket komplit yang sangat lengkap sebagai buku panduan anak-anak dalam mempelajari bahasa Inggris sejak dini. Tidak hanya bahasa Inggris saja namun di dalam English time ini juga terdapat $\mathrm{CD}$, aplikasi yang dapat digunakan untuk menambah wawasan siswa dalam pemahaman mengenai komputerisasi dan multimedia. Sehingga media English Time ini menjadikan anak lebih cepat dalam menguasai bahasa Inggris.

Pembelajaran bahasa Inggris dalam English Time ini di SD Semai, diperkenalkan secara bertahap mulai dari level 1 (beginner) sampai level advance. Pembelajaran bahasa Inggris seperti Grammar dan Pronunciation di hadirkan secara interaktif melalui multimedia yang membuat anak tertarik untuk belajar bahasa Inggris lebih mendalam. English Time dilengkapi dengan CD ROM yang dapat digunakan untuk menonton dan mendengarkan video, bermain dan berlatih bahasa Inggris. disamping itu English Time juga dilengkapi dengan buku yang sangat menarik bagi anak, dapat digunakan untuk berlatih membaca dan menulis.

Berdasarkan hasil observasi peneliti pada tanggal 14 Oktober 2016 hari jumat aktifitas English Club sangat enjoy dan menyenangkan. Proses kegiatannya adalah: pertama, para siswa sedang menonton video English Time tentang Alphabet, keduasetelah menonton, anak-anak kemudian mengucapkan Alphabet beserta kata benda yang menyertainya dengan didampingi oleh tutor, selanjutnya guru menggunakan strategi Flash Card untuk mengembangkan skil pronounciation siswa. 


\section{Kesimpulan}

Dari hasil penelitian di atas, dapat disimpulkan bahwa:

1. Alasan SD Semai mengiplementasikan strategi MI adalah sebagai berikut: (1) strategi MI berupaya untuk melejitkan setiap siswa sesuai kecerdasan uniknya; (2) strategi MI memiliki karakteristik yaitu menjadikan pembelajaran menjadi menyenangkan dan menarik; dan (3) dengan menggunakan strategi MI maka paradigma guru dan wali murid memiliki satu frame yaitu menganggap bahwa semua anak adalah istimewa.

2. Jenis-jenis strategi MI yang diimplementasikan dalam pembelajaran bahasa Inggris meliputi: (1) strategi klasifikasi; (2) strategi identifikasi; (3) strategi sosiodrama; (4) strategi gambar visual; (5) strategi applied learning; (6) strategi Flash-Card; (7) strategi games; dan (8) strategi parodi.

3. Faktor Pendukung Internal; (a) Guru yang memiliki kreatifiats dan semangat yang tinggi dan (b) Siswa yang aktif dan memiliki rasa ingin tahu yang tinggi. Faktor Pendukung Eksternal yaitu: (a) wali murid yang memiliki kepedulian dan mendukung aktifitas sekolah dan (b) dinas yang merespon positif keberadaan SD Semai.

4. Faktor Penghambat Internal yaitu keterbatasan waktu untuk guru dalam mempersiapkan semua administrasi kelas.

\section{Daftar Pustaka}

Andriyani. 2011. Meningkatkan Kemampuan Menyimak Bahasa Inggris dengan Metode Total Phsycal Response (TPR) pada usia TK. Srikspi PG PAUD UPI: tidak diterbitkan.

Campbell, Linda, dkk. 2002. Multiple Intelligences, Metode Terbaru Melesatkan Kecerdasan. Depok: Inisiasi Press.

Chatib, Munif. 2011. Gurunya Manusia, Bandung : Kaifa.

Creswell, J.W.2007. Qualitative inquiry \& research design (2nd ed). London: Sage Publications. 
2010. Research design "pendekatan kualitatif, kuantitatif, dan mixed”. (Terjemahan Achmad Fawaid). London: Sage Publications. (Buku Asli diterbitkan 1994).

Kamilah, Siti. 2015. Implementasi Pendekatan Multiple Intelligences dalam Pembelajaran Anak Usia Dini di Playgroup dan Kindergarden ANANDA MENTARI Condongcatur Yogyakarta. Diakses pada tanggal 19 Mei 2016 melalui http://www.google.co.id/url? $\mathrm{sa}=\mathrm{t} \& \mathrm{rct}=\mathrm{j} \& \mathrm{q}=\& \mathrm{esrc}=\mathrm{s} \&$ source $=$ web $\&$ $\mathrm{cd}=3 \& \mathrm{ved}=0$ ahUKEwjfs8-w4uXMAhWJmpQKHRtrC8AQFggqMAI\& url $=\mathrm{http} \% 3 \mathrm{~A} \% 2 \mathrm{~F} \% 2 \mathrm{Fperpus}$.iainsalatiga.ac.id $\% 2 \mathrm{Fdocfiles} \% 2 \mathrm{Ffulltext} \% 2 \mathrm{~F} 8$ 5f64fc112f3051d.pdf\&usg=AFQjCNFyE42tNxLo5nTZQQHbngLPIUo4FQ \&sig2=1AM9AlTOzVyvJHAFgvatOQ

Mason, J. 2006. Qualitative researching. London: Sage Publications Ltd.

Moleong, L.J. 2004. Metodologi penelitian kualitatif. Bandung: Remaja Rosdakarya.

Muhajir, N. 2002. Metodologi penelitian kualitatif (rev. ed.3). Yogyakarta: Sarasin.

Musfiroh, Tadkiroatun. 2008. Pengembangan Kecerdasan majemuk, Jakarta: Universitas terbuka.

Semai. 2013.Semai Rintisan Sekolahnya Manusia. Di akses pada tanggal 19 Mei 2016 melalui https://goresangurusemai.wordpress.com/2013/08/23/semairintisan-sekolahnya-manusia-di-bumi-jepara/

Thohiroh, Muflihatun. 2013. Implementasi Multiple Intelligences dalam Pembelajaran pada SD Berbasis Islam di kota Magelang; Studi Kasus di SD Muhammadiyah 1 Alternatif dan SDIT Ihsanul Fikri Kota Magelang. Di akses pada tanggal 19 Mei 2016 melalui http://www. google.co $. i d / u r l ? s a=t \& r c t=j \& q=\&$ esrc $=$ s\& source $=$ web\&cd $=6 \& v e d=0$ ahUKEwjfs $8-$ w4uXMAhWJmpQKHRtrC8AQFghAMAU\&url=http\%3A\%2F\%2Fdigilib.u in-suka.ac.id\%2F16013\%2F1\%2FBAB $\% 2520 \mathrm{I} \quad \% 2 \mathrm{C} \% 2520 \mathrm{~V} \% 2 \mathrm{C} \% 2520$ DAFTAR\%2520PUSTAKA.pdf\&usg=AFQjCNEOTxzeVqtXn4PPRtU1Cb0WwdcwA\&sig2=xpDCFjSsRtZoAVHpY2ouNA

Yin, R.K. 2012. Studi kasus: desain \& metode. (cet. ke-13). Jakarta: PT. Raja Grafindo Persada. 
140 Santi Andriyani

Implementasi Strategi Multiple Intelligences pada Pembelajaran Bahasa Inggris

(Studi Kasus di SD Inklusi Semai Jepara) 